\title{
Operando XAFS studies of supported copper oxides for catalytic ammonia combustion
}

\author{
Satoshi HINOKUMA ${ }^{* \dagger}$, Yusuke KAWABATA, Saaya KIRITOSHI, Shun MATSUKI and Masato MACHIDA \\ Department of Applied Chemistry and Biochemistry, Graduate School of Science and Technology, Kumamoto University, \\ 2-39-1 Kurokami, Chuo-ku, Kumamoto 860-8555, Japan \\ *Japan Science and Technology Agency, Precursory Research for Embryonic Science and Technology, \\ 4-1-8 Honcho, Kawaguchi, Saitama 332-0012, Japan
}

Local structures around copper oxides $\left(\mathrm{CuO}_{x}\right)$ supported on aluminum oxide borates (10A2B) during the $\mathrm{NH}_{3}$ combustion reaction were studied by operando $\mathrm{XAFS}$. Although $\mathrm{CuO}_{x}$ in as-prepared $\mathrm{CuO}_{x} / 10 \mathrm{~A} 2 \mathrm{~B}$ at room temperature can be assigned to $\mathrm{CuO}$, the $\mathrm{CuO}$ was partly reduced to $\mathrm{Cu}_{2} \mathrm{O}$ during $\mathrm{NH}_{3}$ combustion at $400^{\circ} \mathrm{C}$. In contrast, $\mathrm{CuAl}_{2} \mathrm{O}_{4}$ was formed after thermal aging of $\mathrm{CuO}_{x} / 10 \mathrm{~A} 2 \mathrm{~B}$ at $900^{\circ} \mathrm{C}$ for $100 \mathrm{~h}$ in air, local structures of which were preserved during $\mathrm{NH}_{3}$ combustion at $600^{\circ} \mathrm{C}$. (O2017 The Ceramic Society of Japan. All rights reserved.

Key-words : Operando XAFS, Supported catalysts, Copper oxides, Ammonia combustion

[Received March 31, 2017; Accepted May 3, 2017]

In order to elucidate the actual dynamics of catalysis, the investigation of the local structures during catalytic reactions is essential. Recently, operando X-ray absorption fine structure (XAFS) measurements have made dramatic progress for use as a powerful technique to study the local structures of catalysts under reaction conditions. ${ }^{1)-12)}$ Kornienko et al. revealed a molecular model of an amorphous cobalt sulfide catalyzing hydrogen evolution reactions by operando XAFS and Raman. ${ }^{6}$ Li et al. developed a novel micro-reactor compatible with operando XAFS and scanning transmission electron microscopy (STEM) observation to obtain complex structural dynamics of nanocatalysts. ${ }^{7)}$ Operando XAFS study of metal oxide catalysts during the water-gas shift reaction was prospected by Rodriguez et al., who also reported their partial reduction behavior. ${ }^{11)}$ Doronkin et al. elucidated the local structures of iron- and copper-containing zeolites during the selective catalytic reduction (SCR) of $\mathrm{NO}_{x}$ by $\mathrm{NH}_{3}$, and finally concluded their catalysis and SCR mechanism from the operando XAFS study. ${ }^{3)}$ Therefore, operando XAFS has a great impact on the study of the actual local structures during catalytic reactions as well as the reaction mechanisms.

$\mathrm{NH}_{3}$ has recently been regarded as a renewable and carbon-free energy source due to its high energy density, ${ }^{13)}$ but it has problems including high ignition temperature and $\mathrm{N}_{2} \mathrm{O} / \mathrm{NO}_{x}$ production, in comparison with fossil fuels. Previously, we proposed novel catalytic $\mathrm{NH}_{3}$ combustion systems that enable low ignition temperatures as well as negligible $\mathrm{N}_{2} \mathrm{O} / \mathrm{NO}_{x}$ emissions, ${ }^{14)-16 \text { ) }}$ and reported that the $\mathrm{NH}_{3}$ combustion activity of metal oxides increases with a decrease in their metal-oxygen bond energy. ${ }^{14)}$ In addition, a novel catalyst, copper oxide $\left(\mathrm{CuO}_{x}\right)$ supported on aluminum oxide borates $\left(10 \mathrm{Al}_{2} \mathrm{O}_{3} \cdot 2 \mathrm{~B}_{2} \mathrm{O}_{3}: 10 \mathrm{~A} 2 \mathrm{~B}\right)$ with high performance for $\mathrm{NH}_{3}$ combustion, was successfully prepared. ${ }^{15)}$ Although $\mathrm{CuO}_{x}$-based catalysts have also been widely studied for the selective oxidation of $\mathrm{NH}_{3}$ emissions to reduce air pollution, ${ }^{17), 18)}$ there are no published studies of the catalytic local structures during $\mathrm{NH}_{3}$ combustion and/or the oxidation reaction

\footnotetext{
Corresponding author: S. Hinokuma; E-mail: hinokuma@ kumamoto-u.ac.jp

* Preface for this article: Dol http://doi.org/10.2109/jcersj2.125.P10-1
}

over the well-known supported $\mathrm{CuO}_{x}$. Therefore, in this study, the local structures around $\mathrm{Cu}$ in the previously developed $\mathrm{CuO}_{x}$ / $10 \mathrm{~A} 2 \mathrm{~B}$ and in the conventional $\mathrm{CuO}_{x} / \mathrm{Al}_{2} \mathrm{O}_{3}$ under $\mathrm{NH}_{3}$ combustion reaction conditions were elucidated by operando XAFS for the first time. Finally, taking our previous reports into account, the catalysis process is discussed.

$\mathrm{CuO}_{x} / 10 \mathrm{~A} 2 \mathrm{~B}$ and $\mathrm{CuO}_{x} / \mathrm{Al}_{2} \mathrm{O}_{3}$ were prepared by a conventional impregnation method, the details of which are shown in the Supporting Information. To evaluate their thermal stability, the asprepared catalysts were thermally aged at $900^{\circ} \mathrm{C}$ for $100 \mathrm{~h}$ in air. Operando XAFS for $\mathrm{Cu}$ K-edge was obtained at the BL9A station of the Photon Factory (PF), High Energy Accelerator Research Organization (KEK). The sample was placed in a temperaturecontrollable cell (Figure S1) and heated from room temperature to $600{ }^{\circ} \mathrm{C}$ at a heating rate of $10^{\circ} \mathrm{C} \cdot \mathrm{min}^{-1}$ in a gas mixture of $\mathrm{NH}_{3}(1.0 \%), \mathrm{O}_{2}(1.5 \%)$, and $\mathrm{He}$ (balance) at a flow rate of 100 $\mathrm{cm}^{3} \cdot \mathrm{min}^{-1}$. The $\mathrm{O}_{2}$-excess ratio of $\mathrm{NH}_{3}$ combustion was expressed as $\lambda=\left(p \mathrm{O}_{2} / p \mathrm{NH}_{3}\right)_{\text {exp. }} /\left(p \mathrm{O}_{2} / p \mathrm{NH}_{3}\right)_{\text {stoichiom }}(\lambda=2)$. The $\mathrm{Cu}$ K-edge XAFS spectra were recorded during the catalytic $\mathrm{NH}_{3}$ combustion at reaction temperatures of 200,400 , and $600^{\circ} \mathrm{C}$ for $30 \mathrm{~min}$. These spectra were measured in the transmission mode using an ionization chamber filled with $\mathrm{N}_{2}$ for the incident beam, another chamber filled with $75 \% \mathrm{~N}_{2}+25 \%$ Ar for the transmitted beam, and a $\mathrm{Si}(111)$ double-crystal monochromator. Reference samples $\left(\mathrm{Cu}_{2} \mathrm{O}, \mathrm{CuO}\right.$, and $\left.\mathrm{CuAl}_{2} \mathrm{O}_{4}\right)$ were mixed with boron nitride $(\mathrm{BN})$ powder to achieve an appropriate absorbance at the edge energy. The XAFS data were processed using the IFEFFIT software package (Athena and Artemis). EXAFS oscillations were extracted by fitting a cubic spline function through the post-edge region. The $k^{3}$-weighted EXAFS oscillation in the $2.0-15.0 \AA^{-1}$ region was Fourier transformed.

Figure 1 shows the normalized $\mathrm{Cu} \mathrm{K}$-edge X-ray absorption near edge structure (XANES) spectra for the catalysts during $\mathrm{NH}_{3}$ combustion $(\lambda=2)$ at room temperature, 200,400 , and $600^{\circ} \mathrm{C}$ together with the spectra for three references. Compared with the references, the XANES spectrum for as-prepared $\mathrm{CuO}_{x} / 10 \mathrm{~A} 2 \mathrm{~B}$ at room temperature (RT) was similar to that for $\mathrm{CuO}$, which is consistent with our previous studies of their X-ray diffraction (XRD) patterns. ${ }^{15)}$ Moreover, the catalysts exhibited a weak pre- 


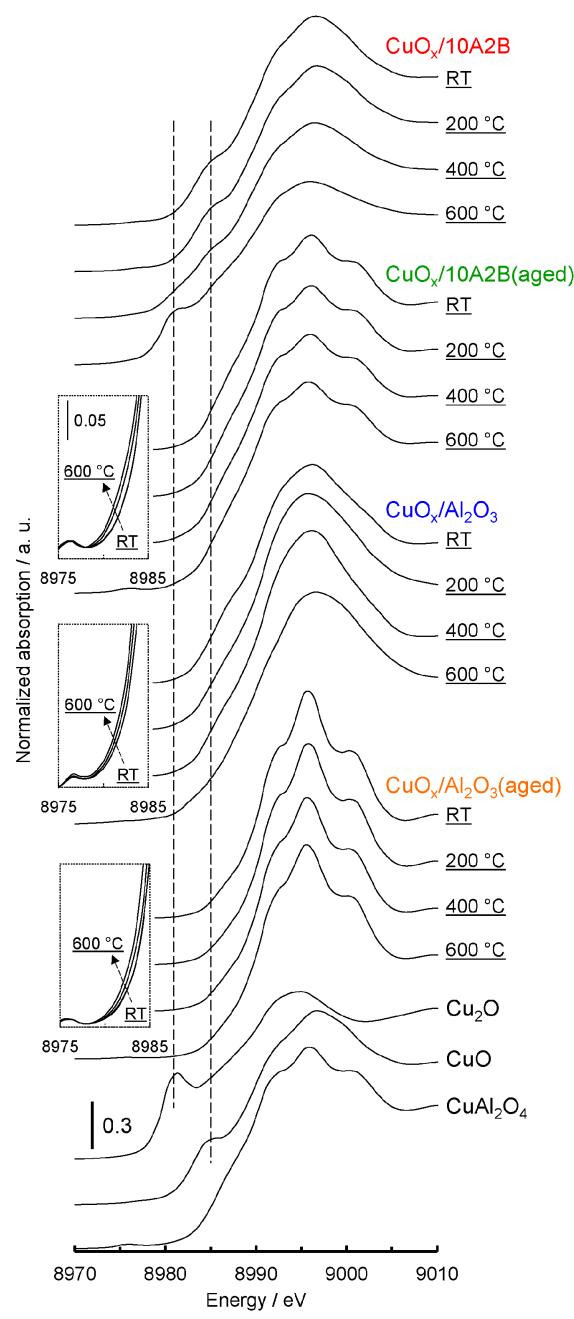

Fig. 1. Normalized Cu K-edge XANES spectra for the catalysts during $\mathrm{NH}_{3}$ combustion and the references.

edge (at approximately $8985 \mathrm{eV}$ assigned to $\mathrm{Cu}^{2+} 1 \mathrm{~s} \rightarrow 4 \mathrm{p}+$ ligand, and $\mathrm{Cu}^{2+} 1 \mathrm{~s} \rightarrow \mathrm{Cu}^{2+}$ charge-transfer excitation ${ }^{5)}$ ), which was observed in the XANES spectrum of $\mathrm{CuO}$. Although the spectrum for $\mathrm{CuO}_{x} / 10 \mathrm{~A} 2 \mathrm{~B}$ at $200^{\circ} \mathrm{C}$ was also similar to that for $\mathrm{CuO}$, the absorption energy of the XANES spectra for $\mathrm{CuO}_{x} /$ 10A2B shifted to lower energy when increasing the combustion temperature to $400^{\circ} \mathrm{C}$. Subsequently, the absorption energy of the spectrum for $\mathrm{CuO}_{x} / 10 \mathrm{~A} 2 \mathrm{~B}$ at $600^{\circ} \mathrm{C}$ exhibited a weak preedge assigned to $\mathrm{Cu}^{+} 1 \mathrm{~s} \rightarrow 4 \mathrm{p}$ transition, ${ }^{5)}$ which was observed in the spectrum for $\mathrm{Cu}_{2} \mathrm{O}$. According to linear combination fitting (Table $\mathrm{S} 1$ ), $\mathrm{CuO}$ in $\mathrm{CuO}_{x} / 10 \mathrm{~A} 2 \mathrm{~B}$ at $600^{\circ} \mathrm{C}$ was reduced approximately $50 \%$ to $\mathrm{Cu}_{2} \mathrm{O}$. These results imply that $\mathrm{CuO}\left(\mathrm{Cu}^{2+}\right)$ in asprepared $\mathrm{CuO}_{x} / 10 \mathrm{~A} 2 \mathrm{~B}$ was partly changed, i.e. reduced, to $\mathrm{Cu}_{2} \mathrm{O}$ $\left(\mathrm{Cu}^{+}\right)$during the $\mathrm{NH}_{3}$ combustion reaction. We have previously demonstrated the following catalytic properties of $\mathrm{CuO}_{x} / 10 \mathrm{~A} 2 \mathrm{~B}$ and $\mathrm{CuO}_{x} / \mathrm{Al}_{2} \mathrm{O}_{3}$ : (1) these catalysts could be characterized by highly dispersed $\mathrm{CuO}_{x}$ nanoparticles, (2) their light-off curves of $\mathrm{NH}_{3}$ were obtained at approximately $300^{\circ} \mathrm{C}$, (3) the catalytic $\mathrm{NH}_{3}$ combustions proceeded via the Mars-van Krevelen mechanism, (4) the lattice oxygen of $\mathrm{CuO}_{x}$ nanoparticles reacted with $\mathrm{NH}_{3}$, and therefore its surface was reduced. ${ }^{15)}$ Such reduction behavior is in agreement with the previous X-ray photoelectron spectroscopy (XPS) analysis. ${ }^{15)}$ Unlike the as-prepared $\mathrm{CuO}_{x} / 10 \mathrm{~A} 2 \mathrm{~B}$, on the other hand, the XANES spectra for $\mathrm{CuO}_{x} / 10 \mathrm{~A} 2 \mathrm{~B}$ (aged) at RT

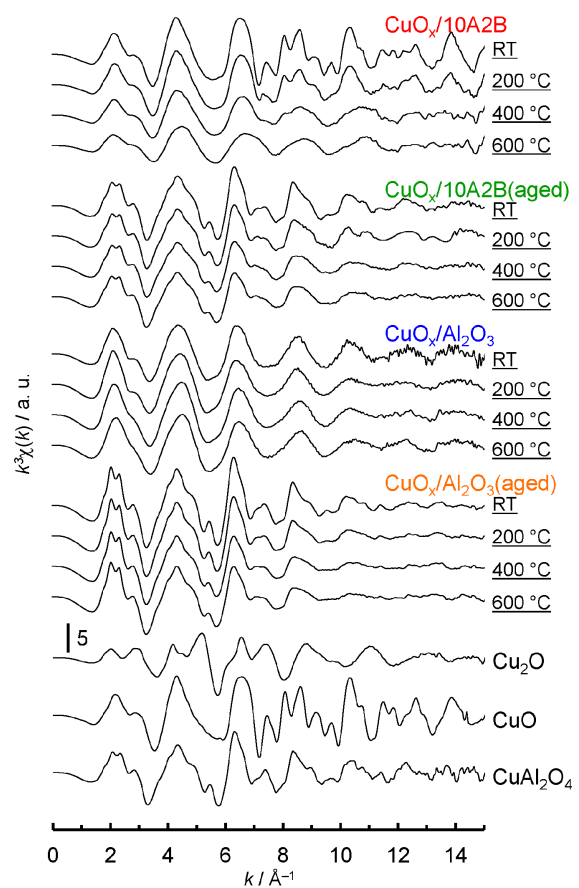

Fig. 2. $\mathrm{Cu}$ K-edge EXAFS oscillations for the catalysts during $\mathrm{NH}_{3}$ combustion and the references.

and $200^{\circ} \mathrm{C}$ were similar to the spectrum for spinel $\mathrm{CuAl}_{2} \mathrm{O}_{4}$ due to the solid-state reaction between as-prepared $\mathrm{CuO}$ and $10 \mathrm{~A} 2 \mathrm{~B}$. Therefore, considering the XPS analysis, ${ }^{15)}$ it is probable that the oxidation state of the bulk $\mathrm{CuAl}_{2} \mathrm{O}_{4}$ in $\mathrm{CuO}_{x} / 10 \mathrm{~A} 2 \mathrm{~B}$ (aged) was also 2+ during the $\mathrm{NH}_{3}$ combustion reaction, whereas the surface of $\mathrm{CuAl}_{2} \mathrm{O}_{4}$ was reduced to the lower oxidation state. Similar structures as well as trends were also observed in $\mathrm{CuO}_{x} / \mathrm{Al}_{2} \mathrm{O}_{3}$ before and after thermal aging.

Figure 2 shows the extended X-ray absorption fine structure (EXAFS) oscillations for the catalysts during $\mathrm{NH}_{3}$ combustion $(\lambda=2)$. In the case of as-prepared $\mathrm{CuO}_{x} / 10 \mathrm{~A} 2 \mathrm{~B}$, its oscillation was similar to that for $\mathrm{CuO}$, which is consistent with the results of XANES (Fig. 1) and XRD. The oscillation for $\mathrm{CuO}_{x} / 10 \mathrm{~A} 2 \mathrm{~B}$ at $200^{\circ} \mathrm{C}$ was also similar to that for $\mathrm{CuO}$, whereas its oscillations at 400 and $600^{\circ} \mathrm{C}$ became similar to that for $\mathrm{Cu}_{2} \mathrm{O}$, which indicates that the $\mathrm{CuO}$ nanoparticles of as-prepared $\mathrm{CuO}_{x} / 10 \mathrm{~A} 2 \mathrm{~B}$ were partly reduced to $\mathrm{Cu}_{2} \mathrm{O}$ during the $\mathrm{NH}_{3}$ combustion reaction at temperatures higher than $300^{\circ} \mathrm{C}$. Moreover, the amplitude of the oscillation for $\mathrm{CuO}_{x} / 10 \mathrm{~A} 2 \mathrm{~B}$ tends to decrease with increasing the reaction temperature. In contrast, in the cases of $\mathrm{CuO}_{x} /$ $10 \mathrm{~A} 2 \mathrm{~B}$ (aged), as-prepared $\mathrm{CuO}_{x} / \mathrm{Al}_{2} \mathrm{O}_{3}$, and $\mathrm{CuO}_{x} / \mathrm{Al}_{2} \mathrm{O}_{3}$ (aged) at each reaction temperature, their oscillations were similar to that for $\mathrm{CuAl}_{2} \mathrm{O}_{4}$. However, the amplitudes of their oscillations also decrease upon reaching the reaction temperature of $400^{\circ} \mathrm{C}$.

Figure 3 shows Fourier transforms (FT) of $k^{3}$-weighted $\mathrm{Cu} \mathrm{K}$ edge EXAFS for the catalysts. At RT and $200^{\circ} \mathrm{C}$, the as-prepared $\mathrm{CuO}_{x} / 10 \mathrm{~A} 2 \mathrm{~B}$ displayed an intense $\mathrm{Cu}-\mathrm{O}$ peak $(r \sim 1.95 \AA)$ attributed to $\mathrm{CuO}$. Upon reaching the reaction temperature of $400^{\circ} \mathrm{C}$, the catalyst displayed an intense $\mathrm{Cu}-\mathrm{O}$ peak $(r \sim 1.85 \AA)$ attributed to $\mathrm{Cu}_{2} \mathrm{O}$. These results are in agreement with the XANES and EXAFS oscillations, and it is suggested that the structure of $\mathrm{CuO}$ in the as-prepared $\mathrm{CuO}_{x} / 10 \mathrm{~A} 2 \mathrm{~B}$ was partly changed (reduced) to that of $\mathrm{Cu}_{2} \mathrm{O}$ during the $\mathrm{NH}_{3}$ combustion reaction. On the other hand, the other catalysts, $\mathrm{CuO}_{x} / 10 \mathrm{~A} 2 \mathrm{~B}$ (aged) and $\mathrm{CuO}_{x} / \mathrm{Al}_{2} \mathrm{O}_{3}$ before and after thermal aging, displayed an intense $\mathrm{Cu}-\mathrm{O}$ peak $(r \sim 1.94 \AA)$ attributed to $\mathrm{CuAl}_{2} \mathrm{O}_{4}, r$ of which were preserved 


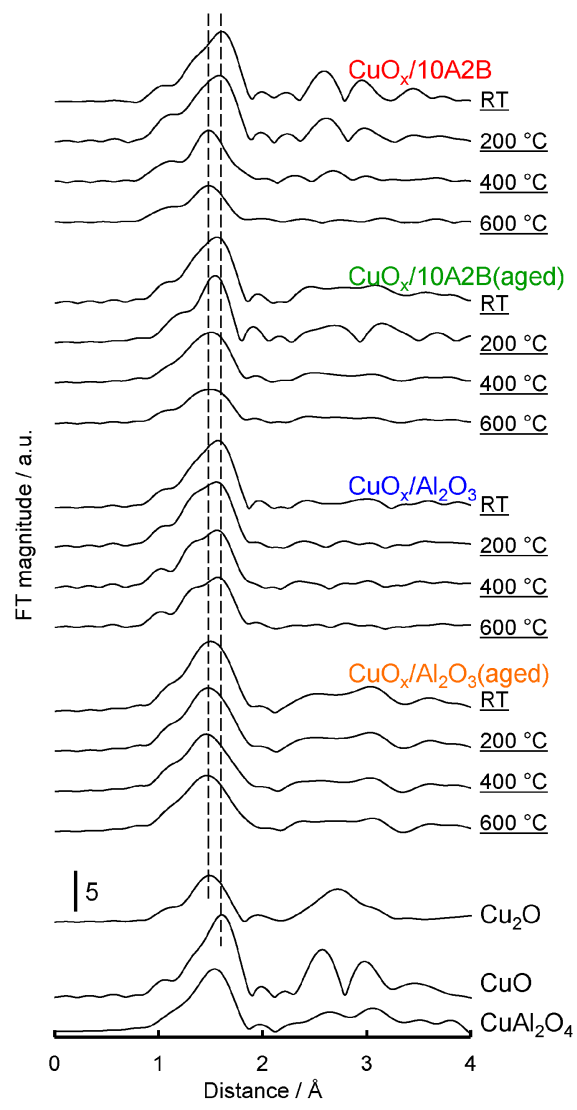

Fig. 3. Fourier transforms of $k^{3}$-weighted $\mathrm{Cu} \mathrm{K}$-edge EXAFS for the catalysts during $\mathrm{NH}_{3}$ combustion and the references.

after heating at $600^{\circ} \mathrm{C}$. These results indicate the catalysts also form spinel $\mathrm{CuAl}_{2} \mathrm{O}_{4}$ during the $\mathrm{NH}_{3}$ combustion reaction.

Based on the present and previous results, the local structures of supported $\mathrm{CuO}_{x}$ during catalytic $\mathrm{NH}_{3}$ combustion $(\lambda=2)$ can be suggested, as depicted in Figure $\mathrm{S} 2 . \mathrm{CuO}_{x}$ in the as-prepared $\mathrm{CuO}_{x} / 10 \mathrm{~A} 2 \mathrm{~B}$ can be assigned to $\mathrm{CuO}$ nanoparticles before the combustion, whereas the structure of $\mathrm{CuO}$ was partly changed to that of $\mathrm{Cu}_{2} \mathrm{O}$ during the $\mathrm{NH}_{3}$ combustion. These results imply that a mixture of $\mathrm{CuO}$ and $\mathrm{Cu}_{2} \mathrm{O}$ nanoparticles exists during the combustion, and the catalytic $\mathrm{NH}_{3}$ combustion over $\mathrm{CuO}$ nanoparticles in the catalysts probably proceeds by redox cycling between $\mathrm{CuO}$ and $\mathrm{Cu}_{2} \mathrm{O}$. On the other hand, the $\mathrm{CuAl}_{2} \mathrm{O}_{4}$ nanoparticles in other catalysts preserved the local structure of its spinel $\mathrm{CuAl}_{2} \mathrm{O}_{4}$ even during the $\mathrm{NH}_{3}$ combustion. However, because the reduction of surface $\mathrm{CuAl}_{2} \mathrm{O}_{4}$ was obtained after the $\mathrm{NH}_{3}$ combustion reaction from previous XPS analysis, it is probable that the catalytic $\mathrm{NH}_{3}$ combustion over $\mathrm{CuAl}_{2} \mathrm{O}_{4}$ nanoparticles proceeds by redox cycling of surface $\mathrm{CuAl}_{2} \mathrm{O}_{4}$.

In conclusions, the local structures around $\mathrm{CuO}_{x}$ nanoparticles in $\mathrm{CuO}_{x} / 10 \mathrm{~A} 2 \mathrm{~B}$ and $\mathrm{CuO}_{x} / \mathrm{Al}_{2} \mathrm{O}_{3}$ during the catalytic combustion $(\lambda=2)$ of $\mathrm{NH}_{3}$ were studied by means of operando $\mathrm{Cu} \mathrm{K}$ edge XANES and EXAFS. From the XANES spectra, the nanoparticles of $\mathrm{CuO}\left(\mathrm{Cu}^{2+}\right)$ in the as-prepared $\mathrm{CuO}_{x} / 10 \mathrm{~A} 2 \mathrm{~B}$ were reduced by approximately $50 \%$ to $\mathrm{Cu}_{2} \mathrm{O}\left(\mathrm{Cu}^{+}\right)$at a reaction temperature of $600^{\circ} \mathrm{C}$, whereas the oxidation state of the bulk $\mathrm{CuAl}_{2} \mathrm{O}_{4}$ nanoparticles in the other catalysts was barely changed. According to the profiles of EXAFS oscillations and FT-EXAFS, similar behaviors of catalytic reductions were obtained. In addition, the local structure of $\mathrm{CuO}$ nanoparticles in the $\mathrm{CuO}_{x} / 10 \mathrm{~A} 2 \mathrm{~B}$ partly changed to $\mathrm{Cu}_{2} \mathrm{O}$ nanoparticles during $\mathrm{NH}_{3}$ combustion. In contrast, the local structure of the bulk $\mathrm{CuAl}_{2} \mathrm{O}_{4}$ nanoparticles was preserved during the $\mathrm{NH}_{3}$ combustion reaction. From our previous XPS analysis, however, it is considered that the surface of $\mathrm{CuAl}_{2} \mathrm{O}_{4}$ in the other catalysts was reduced during the $\mathrm{NH}_{3}$ combustion reaction at $400^{\circ} \mathrm{C}$, because $\mathrm{NH}_{3}$ reacts with the lattice oxygen of $\mathrm{CuAl}_{2} \mathrm{O}_{4}$, and therefore the catalytic $\mathrm{NH}_{3}$ combustion proceeds via the Mars-van Krevelen mechanism.

Acknowledgements This research was supported by JST, PRESTO (JPMJPR1344). Operando XAFS experiments were performed at the BL9A with the approval of PF, KEK (Proposal No. 2016G527).

Supporting Information Catalyst preparation, linear combination fitting parameters, experimental setup, and possible changes for the local structures of supported $\mathrm{CuO}_{x}$.

\section{References}

1) Y. Iwasawa, K. Asakura and M. Tada, "XAFS Techniques for Catalysts, Nanomaterials, and Surfaces", Springer Nature, Switzerland (2017).

2) E. Bayram, J. Linehan, J. Fulton, J. Roberts, N. Szymczak, T. Smurthwaite, S. Ozkar, M. Balasubramanian and R. Finke, J. Am. Chem. Soc., 133, 18889-18902 (2011).

3) D. Doronkin, M. Casapu, T. Gunter, O. Muller, R. Frahm and J. Grunwaldt, J. Phys. Chem. C, 118, 10204-10212 (2014).

4) J. Fulton, J. Linehan, T. Autrey, M. Balasubramanian, Y. Chen and N. Szymczak, J. Am. Chem. Soc., 129, 11936-11949 (2007).

5) F. Giordanino, E. Borfecchia, K. Lomachenko, A. Lazzarini, G. Agostini, E. Gallo, A. Soldatov, P. Beato, S. Bordiga and C. Lamberti, J. Phys. Chem. Lett., 5, 1552-1559 (2014).

6) N. Kornienko, J. Resasco, N. Becknell, C. Jian, Y. Liu, K. Nie, X. Sun, J. Guo, S. Leone and P. Yang, J. Am. Chem. Soc., 137, 7448-7455 (2015)

7) Y. Li, D. Zakharov, S. Zhao, R. Tappero, U. Jung, A. Elsen, P. Baumann, R. Nuzzo, E. Stach and A. Frenkel, Nat. Commun., 6, 7583 (2015).

8) K. Lomachenko, E. Borfecchia, C. Negri, G. Berlier, C. Lamberti, P. Beato, H. Falsig and S. Bordiga, J. Am. Chem. Soc., 138, 12025-12028 (2016).

9) M. Newton, J. Brazier, E. Barreiro, S. Parry, H. Emmerich, L. Adrio, C. Mulligan, K. Hellgardt and K. Hii, Green Chem., 18, 406-411 (2016).

10) E. Peterson, A. Delariva, S. Lin, R. Johnson, H. Guo, J. Miller, J. Kwak, C. Peden, B. Kiefer, L. Allard, F. Ribeiro and A. Datye, Nat. Commun., 5, 4885 (2014).

11) J. Rodriguez, J. Hanson, D. Stacchiola and S. Senanayake, Phys. Chem. Chem. Phys., 15, 12004-12025 (2013).

12) R. Rousseau, G. Schenter, J. Fulton, J. Linehan, M. Engelhard and T. Autrey, J. Am. Chem. Soc., 131, 10516-10524 (2009).

13) A. Hayakawa, T. Goto, R. Mimoto, T. Kudo and H. Kobayashi, Mech. Eng. J., 2, 14-00402 (2015).

14) S. Hinokuma, H. Shimanoe, S. Matsuki, M. Kawano, Y Kawabata and M. Machida, Chem. Lett., 45, 179-181 (2016).

15) S. Hinokuma, S. Matsuki, Y. Kawabata, H. Shimanoe, S Kiritoshi and M. Machida, J. Phys. Chem. C, 120, 24734 24742 (2016).

16) S. Hinokuma, Y. Kawabata, S. Matsuki, H. Shimanoe, S Kiritoshi and M. Machida, J. Phys. Chem. C, 121, 4188-4196 (2017).

17) L. Chmielarz and M. Jablonska, RSC Advances, 5, 4340843431 (2015).

18) M. Jablonska and R. Palkovits, Appl. Catal., B-Environ, 181, 332-351 (2016). 